\title{
Enhanced Virulence of Aeromonas hydrophila Is Induced by Stress and Serial Passaging in Mice
}

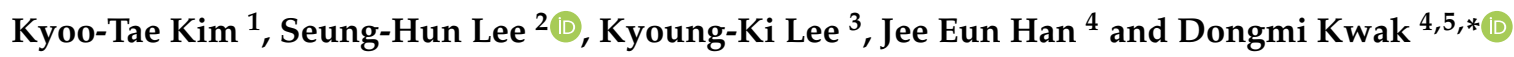 \\ 1 Animal Health Center of Zoo Land, Daejeon O-World Theme Park, Daejeon 35073, Korea; ktkim95@korea.kr \\ 2 College of Veterinary Medicine, Chungbuk National University, Cheongju 28644, Korea; \\ dvmshlee@chungbuk.ac.kr \\ 3 Animal Disease Diagnostic Division, Animal and Plant Quarantine Agency, Gimcheon 39660, Korea; \\ naturelkk@korea.kr \\ 4 College of Veterinary Medicine, Kyungpook National University, Daegu 41566, Korea; jehan@knu.ac.kr \\ 5 Cardiovascular Research Institute, Kyungpook National University, Daegu 41944, Korea \\ * Correspondence: dmkwak@knu.ac.kr; Tel.: +82-53-950-7794
}

Citation: Kim, K.-T.; Lee, S.-H.; Lee, K.-K.; Han, J.E.; Kwak, D. Enhanced Virulence of Aeromonas hydrophila Is Induced by Stress and Serial Passaging in Mice. Animals 2021, 11, 508. https://doi.org/10.3390/ ani11020508

Academic Editor: Tadaaki Satou

Received: 4 January 2021

Accepted: 13 February 2021

Published: 16 February 2021

Publisher's Note: MDPI stays neutral with regard to jurisdictional claims in published maps and institutional affiliations.

Copyright: (c) 2021 by the authors. Licensee MDPI, Basel, Switzerland. This article is an open access article distributed under the terms and conditions of the Creative Commons Attribution (CC BY) license (https:// creativecommons.org/licenses/by/ $4.0 /)$.
Simple Summary: Aeromonas hydrophila, which is an opportunistic zoonotic bacterium, has the ability to infect animals with injuries involving the condition of the aquatic environments. Factors including poor sanitation and water quality, stress, overcrowding, and rough handling can make animals more sensitive to infections and trigger outbreaks of $A$. hydrophila. A. hydrophila was previously isolated from an African black-footed penguin that died while in captivity at a zoo, following clinical signs of depression and anorexia, and in this study, we investigated the effect of stress and serial passaging in mice on $A$. hydrophila virulence. Serial passaging in mice enhanced the virulence of $A$. hydrophila, and $A$. hydrophila infection combined with administration of stress hormones or fasting increased mortality.

Abstract: Aeromonas hydrophila was isolated from an African black-footed penguin (Spheniscus demersus) that died while in zoo captivity. At necropsy, the virulence of $A$. hydrophila appeared to be enhanced by stress, so was assessed in the presence of in vitro and in vivo stressors and serial passaging in mice. Virulence genes from the isolate were amplified by PCR. In vitro assays were conducted to test the hemolytic activity, cytotoxicity, and effect of stress hormones on A. hydrophila virulence. In vivo assays were conducted to test the stress effect on mortality of $A$. hydrophila-infected mice and virulence in mice. Two virulence genes coding for hemolysin (ahh1) and aerolysin (aer $A)$ were detected, and the cytotoxic potential of the isolate was demonstrated in baby hamster kidney and Vero cells. Some or all mice inoculated with $A$. hydrophila and exposed to stress hormones (epinephrine and norepinephrine) or low temperature died, while mice inoculated with $A$. hydrophila and exposed to fasting or agitation stressors or no stressors survived. We concluded that stress can be fatal in mice experimentally infected with $A$. hydrophila and that serial passaging in mice dramatically enhances the virulence of $A$. hydrophila.

Keywords: aerolysin; Aeromonas hydrophila; hemolysin; mice; stress; virulence

\section{Introduction}

Members of the genus Aeromonas are ubiquitous Gram-negative bacilli that are widespread in aquatic environments [1]. Aeromonas spp., as a component of the natural microflora of aquatic bodies, are found in aquatic environments worldwide, including ground, surface, estuarine, marine, waste, and drinking water. Aeromonads are also found in many foods, including fresh produce, seafood, raw meats, packaged ready-to-eat foods, cheese, and milk [2]. Broadly, aeromonads can be divided into motile and non-motile species [3,4]. Several motile Aeromonas species (e.g., A. hydrophila, A. caviae, A. dhakensis, and A. veronii 
biovar sobria) are known as pathogens of aquatic animals, and interest in this genus has increased due to its zoonotic potential [3,4].

Motile Aeromonas is a common agent of motile Aeromonas septicemia, which is also referred to as epizootic ulcerative syndrome. The infection includes tissue swelling, skin ulcers, necrosis, and hemorrhagic septicemia [3-5]. Commonly, Aeromonas septicemia has been reported in aquatic animals [6-9]. In humans, Aeromonas infection does not show any clinical signs, except in cases of immunosuppression, chronic disease, or trauma, but it can lead to severe complications in some cases [10-12]. Moreover, in several freshwater fish both in the farm and field, motile Aeromonas spp. are natural gut microbiota and regarded as opportunistic pathogens; the disease is frequently associated with hemorrhagic septicaemia [13-15].

The virulence factors of Aeromonas spp. are present in two forms: cell-associated structures and extracellular products [16]. Cell-associated structures include pili, flagella, outer membrane proteins, lipopolysaccharide, and capsules. These structural features promote bacterial attachment and protect cells from the host immune response. The major extracellular products include cytotoxic, cytolytic, hemolytic, and enterotoxic proteins [17]. Multiple cytotoxins, aerolysins, hemolysins, and cytotoxic enterotoxins are associated with the virulence of Aeromonas spp. in humans and animals. Aerolysin is a characteristic virulence factor of the genus $[18,19]$.

Cases of Aeromonas infection associated with captivity-induced stress have been reported in aquatic animals, such as spectacled caiman (Caiman crocodilus) and European pond turtle (Emys orbicularis) $[8,20]$. In our previous study, A. hydrophila was isolated from an African black-footed penguin (Spheniscus demersus) that died while in captivity at a zoo, following clinical signs of depression and anorexia with greenish vomitus [7] and we further investigated its virulence in several aspects, such as virulence genes, virulence change in serial passage, and administration of stress hormones or fasting in this study.

\section{Materials and Methods}

\subsection{Compliance with Ethical Standards}

This study was performed in strict accordance with protocols approved by the Institutional Animal Care and Use Committee (approval no. DOTP-200600501) at the Daejeon O-World Theme Park. Animal husbandry, monitoring of health status, and euthanasia criteria were applied as described in the manuscript, and all efforts were made to minimize unnecessary suffering and distress of the animals.

\subsection{Bacterial Isolates and Reference Strain}

From the liver and the intestine of the penguin died while in captivity, a Gram-negative, motile, and rod-shaped bacterium was dominantly isolated by streaking the bacteria on a blood agar plate (Asan Pharmacy, Seoul, Korea). The isolates producing beta hemolysis in the blood agar were identified as A. hydrophila by API 20E/NE rapid identification system (BioMérieux, Craponne, France), and then stored in a tryptic soy broth medium (TSB; Difco, Franklin Lakes, NJ, USA) supplemented with $15 \%$ (v/v) glycerol at $-70{ }^{\circ} \mathrm{C}$ [7]. A reference A. hydrophila strain (KCTC \#2358) was purchased from the Biological Resource Center (Daejeon, Korea). The isolate and reference strains were cultured in TSB at $37^{\circ} \mathrm{C}$ for $24 \mathrm{~h}$ with shaking. Following centrifugation, the supernatants were filtered using a $0.22-\mu \mathrm{m}$ membrane filter (Millipore, Billerica, MA, USA). The filtrates were stored at $-70^{\circ} \mathrm{C}$ until used.

\subsection{Singleplex and Multiplex PCR for A. hydrophila Identification and Virulence Genes}

Bacterial DNA was extracted using a DNA Extraction Kit (Bioneer, Daejeon, Korea) according to the manufacturer's instructions. Two virulence genes were used as PCR targets, as previously described [15]: the extracellular hemolysin gene (ahh1) and aerolysin gene (aerA). In addition, a primer set for A. hydrophila 16S rRNA, which is a housekeeping gene, was used as an internal control [15]. 


\subsection{Hemolytic Activity and Cytotoxicity of the Isolate}

The hemolytic activity of the isolate was evaluated using cell-free hemolytic assay with culture supernatants. Briefly, A. hydrophila culture supernatants $(100 \mu \mathrm{L})$ were serially diluted in $100 \mu \mathrm{L}$ phosphate buffered saline (PBS; $\mathrm{pH} 7.4$ ) and mixed with an equal volume of a $1 \%$ suspension of rabbit erythrocytes in microtiter plates. The plates were incubated at $37^{\circ} \mathrm{C}$ for $1 \mathrm{~h}$, followed by further overnight incubation at $4{ }^{\circ} \mathrm{C}$. The hemolytic activity was recorded as the highest serial dilution that displayed hemolysis [21]. Equal volumes of the reference strain and PBS alone were added as controls.

To study the cytotoxicity, Vero and baby hamster kidney (BHK) cells were grown in Eagle's minimal essential medium with $10 \%$ fetal bovine serum (Gibco, Waltham, MA, USA); 2 mM L-glutamine; 100,000 U/L penicillin; and $10 \mathrm{mg} / \mathrm{mL}$ streptomycin (SigmaAldrich, St. Louis, MO, USA). The cells were incubated in 96-well tissue culture plates at $37^{\circ} \mathrm{C}$ in an atmosphere of $5 \% \mathrm{CO}_{2}$. Confluent monolayers $\left(10^{5} \mathrm{cells} / \mathrm{mL}\right)$ were added to two-fold serial dilutions of bacterial culture supernatants, and the plates were incubated at $37{ }^{\circ} \mathrm{C}$ in a humidified atmosphere of $5 \% \mathrm{CO}_{2}$. The cells were examined using an inverted microscope (Nikon, Tokyo, Japan), and morphological changes in the cells due to A. hydrophila were scored following incubation for 0,3 , and $24 \mathrm{~h}$. Briefly, vacuolating effects with total detachment and destruction of the monolayer including cell death were evaluated, and the highest serial dilution that displayed cytotoxicity was recorded as the cytotoxicity titer according to the method described [21]. Equal volumes of the reference strain and PBS alone were added as controls.

\subsection{Effect of Stress Hormones on the In Vitro Growth of A. hydrophila}

To determine the effect of stress hormones on the in vitro growth of A. hydrophila, the isolated A. hydrophila strain was cultured in TSB at $37^{\circ} \mathrm{C}$ for $18 \mathrm{~h}$, and the turbidity was adjusted to match that of $0.5 \mathrm{McFarland}$ standards $\left(1.5 \times 10^{8} / \mathrm{mL}\right)$ for inoculation. The hormones norepinephrine and epinephrine (Sigma-Aldrich, St. Louis, MO, USA) were prepared at $0.1 \mathrm{M}$ in PBS, and each solution was filtered through a $0.2-\mu \mathrm{m}$ membrane (Millipore). These solutions were further diluted 10-fold in PBS to prepare solutions ranging from $10^{-2}$ to $10^{-5} \mathrm{M}$ [12], which were added to the broth. The growth of A. hydrophila was estimated using McFarland standards after incubation for 0, 24, 48, and $72 \mathrm{~h}$ at room temperature.

\subsection{Effect of Stressors on A. hydrophila Virulence}

To determine whether stress conditions enhanced the mortality of A. hydrophilainfected mice, the effect of epinephrine and norepinephrine stress hormone as well as the physical stressors of fasting, low temperature, and agitation were tested.

Seventy Institute of Cancer Research (ICR) mice (Orient Bio, Seongnam, Korea) with an average age of 6 weeks and body weight of 20-25 g were divided into seven groups, with 10 mice in each group (five males and five females). In the experiment, $1 \mathrm{~mL}$ culture suspension $\left(1.5 \times 10^{8}\right.$ A. hydrophila $)$ was orally administered to each mouse, except those in the group treated with $1 \mathrm{~mL}$ PBS. Then, each group was treated with $1 \mathrm{~mL}$ norepinephrine $(0.1 \mathrm{M} ; \mathrm{AH}+\mathrm{N}), 1 \mathrm{~mL}$ epinephrine $(0.1 \mathrm{M} ; \mathrm{AH}+\mathrm{P})$, low temperature-induced stress at $8{ }^{\circ} \mathrm{C}(\mathrm{AH}+\mathrm{L})$, agitation stress by shaking the cages twice each day at 100 times $/ \mathrm{min}$ for $2 \mathrm{~h}(\mathrm{AH}+\mathrm{S})$, fasting providing only tap water $(\mathrm{AH}+\mathrm{F})$, A. hydrophila alone (AH alone), or PBS without $A$. hydrophila (PBS).

Five mice of the same sex were housed in a standard Plexiglass cage $\left(50 \times 25 \times 17.5 \mathrm{~cm}^{3}\right)$ with temperature $\left(22{ }^{\circ} \mathrm{C} \pm 1{ }^{\circ} \mathrm{C}\right)$ and humidity $(55 \% \pm 5 \%)$ controlled during a reversed 12-h dark/light cycle, with the light period occurring from 8:00 a.m. to 8:00 p.m. Mice except for the fasting group had ad libitum access to tap water and commercial pellets for laboratory animals without any additives (Woosung Feed Co., Daejeon, Korea). The mice were monitored three times a day for health status, and there were no unexpected deaths. Mice were euthanized if they met any of the criteria for early removal (lethargy, hunched posture, ruffled coat, or difficulty standing) to limit suffering. Anesthetic (sodium 
pentobarbital) overdose was used for euthanasia. Living and euthanized mice were counted daily for four days.

\subsection{Necropsy and Histopathology}

All living mice were euthanized at the end of the experiment as described above and subjected to necropsy. Tissue samples including the heart, liver, lung, and small intestine were fixed in $10 \%$ neutral formalin and then embedded in paraffin. The tissue samples were sectioned and the sections stained with hematoxylin and eosin and laid on HistoBond ${ }^{\circledR}$ slides (Lab Monster, Seoul, Korea). The sections were used for Lillie's Gram staining for bacterial identification.

\subsection{In Situ PCR}

Tissue sections were mounted on slides, deparaffinized at $60{ }^{\circ} \mathrm{C}$ for $18 \mathrm{~h}$, immersed first in xylene at $37^{\circ} \mathrm{C}$ for $30 \mathrm{~min}$ and then in absolute ethanol, 75\% ethanol, 50\% ethanol, 25\% ethanol, and water at room temperature. The sections were permeabilized by incubation at room temperature in $0.02 \mathrm{~mol} / \mathrm{L} \mathrm{HCl}$ for $10 \mathrm{~min}$, followed by $0.01 \%$ Triton X-100 for $90 \mathrm{~s}$ proteins were eliminated by incubation with $20 \mu \mathrm{g} / \mathrm{mL}$ protease $\mathrm{K}$ (Gibco) at $37^{\circ} \mathrm{C}$ for $10 \mathrm{~min}$, which was further inactivated by boiling in a microwave for $15 \mathrm{~s}$, and the slide sections were plunged into $20 \%$ acetic acid for 15 s to inactivate endogenous alkaline phosphatase.

PCR was performed by incubating these sections with $50 \mathrm{~mL}$ of $1 \times$ reaction buffer (Gibco), $5 \mathrm{U}$ Taq polymerase, $2.5 \mathrm{mmol} / \mathrm{L} \mathrm{MgCl}_{2}$, $2.5 \mathrm{mmol} \mathrm{dNTP}, 0.4 \mathrm{mmol}$ biotin-14$\mathrm{dCTP}$, and 100 pmol primers for the $16 \mathrm{~S}$ rRNA sequence of $A$. hydrophila, as previously described [15]. The slides were sealed using an assembly tool (Takara, Shiga, Japan) and placed in a thermocycler (Perkin Elmer, Waltham, MA, USA). PCR was performed with 25 cycles of denaturation at $95{ }^{\circ} \mathrm{C}$ for $1 \mathrm{~min}$, annealing at $59{ }^{\circ} \mathrm{C}$ for $1 \mathrm{~min}$, and extension at $72{ }^{\circ} \mathrm{C}$ for $1 \mathrm{~min}$. PCR products were detected using diluted (1:100) normal goat serum for blocking and diluted (1:5000) streptavidin horseradish peroxidase conjugate for detection. The chromogen was 3,3'-diaminobenzidine (DAB; Zymed, San Francisco, CA, USA). The slides were counterstained with hematoxylin.

\subsection{Effect of Serial Passaging on Virulence}

To determine whether the virulence of $A$. hydrophila could be enhanced by serial passaging in mice, the $A$. hydrophila isolated from the liver of the dead penguin was streaked on blood agar (Asan Pharmacy, Seoul, Korea) and incubated at $37^{\circ} \mathrm{C}$ for $18 \mathrm{~h}$ before inoculation into Mueller-Hinton broth (MHB, Difco). The turbidity of the culture suspension was adjusted to $0.5 \mathrm{McF}$ arland standards $\left(1.5 \times 10^{8} / \mathrm{mL}\right)$ before inoculation. A total of 30 ICR mice (average age, 6 weeks; body weight, 20-25 g) were used for infection in each passage. For the first passage, the "oral passage" and "intraperitoneal passage" experimental groups each comprised 10 mice, as did the control group. Mice in the experimental groups were inoculated with $1 \mathrm{~mL} A$. hydrophila suspension adjusted to 0.5 McFarland standards, via the oral and intraperitoneal routes. Control mice were inoculated with an equal volume of PBS. Then, $A$. hydrophila was re-isolated from the liver of the mice by streaking and incubation at $37^{\circ} \mathrm{C}$ for $18 \mathrm{~h}$ on blood agar. The bacterial suspension prepared in $\mathrm{MHB}$ was inoculated again into mice at the dosage of $1.5 \times 10^{8}$ colony forming unit (CFU) per mouse for the second passage. This step was repeated again for the third passage. Cages, food, water, and bedding were confirmed to be A. hydrophila-free before use. Animal husbandry, monitoring of health status, and the criteria for euthanasia were applied as described above, and all efforts were made to reduce the distress and suffering of animals.

After euthanizing the mice, tissue samples were aseptically inoculated onto blood agar (Asan Pharmacy) and MacConkey agar (Difco) and incubated at $37^{\circ} \mathrm{C}$ for $12-18 \mathrm{~h}$. Isolates were identified by API-20E or API-20NE (BioMérieux, Craponne, France). 


\section{Results}

\subsection{Singleplex and Multiplex PCR for A. hydrophila Identification and Virulence Genes}

The ahh1, aerA, and 16S rRNA amplicons were amplified in the A. hydrophila isolate and reference strain (Figure 1). Therefore, the isolate carried the virulence genes for hemolysin and aerolysin.

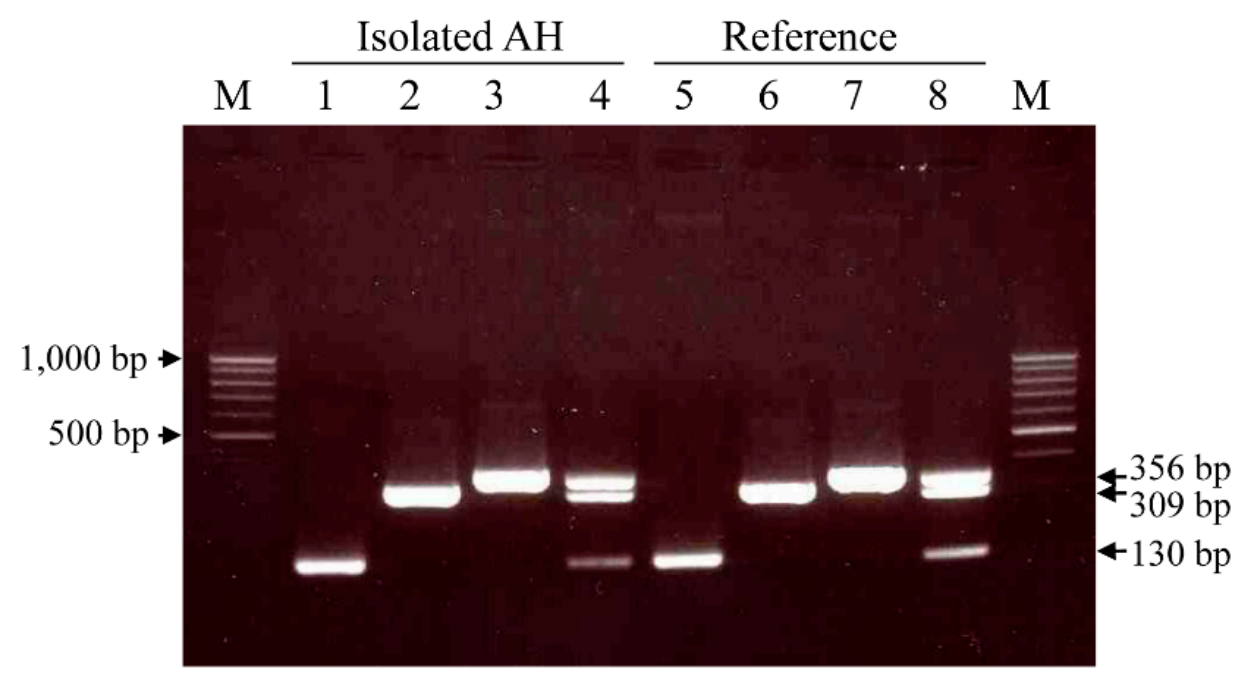

Figure 1. Singleplex and multiplex PCR-based detection of virulence and 16S rRNA genes of Aeromonas hydrophila isolated from a dead African black-footed penguin and the reference strain KCTC \#2358. Lanes: M, 100 bp ladder; 1 and 5: ahh1; 2 and 6: aerA; 3 and 7: 16S rRNA; 4 and 8: triplex PCR.

\subsection{Hemolytic Activity and Cytotoxicity Assay}

The hemolytic activity titer of the A. hydrophila isolate on rabbit erythrocytes (64) was considerably lower than that of the reference strain (256), while the cytotoxicity titer was the same or higher than those of the reference strain in Vero and BHK cells (Table 1).

Table 1. Hemolytic activity and cytotoxicity titers of Aeromonas hydrophila cultured in Vero and baby hamster kidney (BHK) cells.

\begin{tabular}{ccccccccc}
\hline \multirow{2}{*}{ Strain } & \multirow{2}{*}{$\begin{array}{c}\text { Rabbit } \\
\text { Erythrocytes }\end{array}$} & \multicolumn{3}{c}{ Vero Cells } & \multicolumn{3}{c}{ BHK Cells } \\
\cline { 3 - 8 } & & $\mathbf{0 ~ h}$ & $\mathbf{3 ~ h}$ & $\mathbf{2 4} \mathbf{h}$ & $\mathbf{0 ~ h}$ & $\mathbf{3 ~ h}$ & $\mathbf{2 4} \mathbf{~ h}$ \\
\hline Isolate & 64 & 0 & 32 & 256 & 0 & 32 & 512 \\
Reference & 256 & 0 & 16 & 256 & 0 & 16 & 256 \\
PBS & 0 & 0 & 0 & 0 & 0 & 0 & 0 \\
\hline
\end{tabular}

${ }^{1}$ KCTC \#2358.

\subsection{Effect of Stress Hormones on the In Vivo Growth of A. hydrophila}

Norepinephrine treatment led to increased growth of $A$. hydrophila compared to the control, with the effect observed as early as $24 \mathrm{~h}$ (Figure 2). Similar results were observed with epinephrine treatment. The extent of $A$. hydrophila growth decreased with dilution of the stress hormones. 

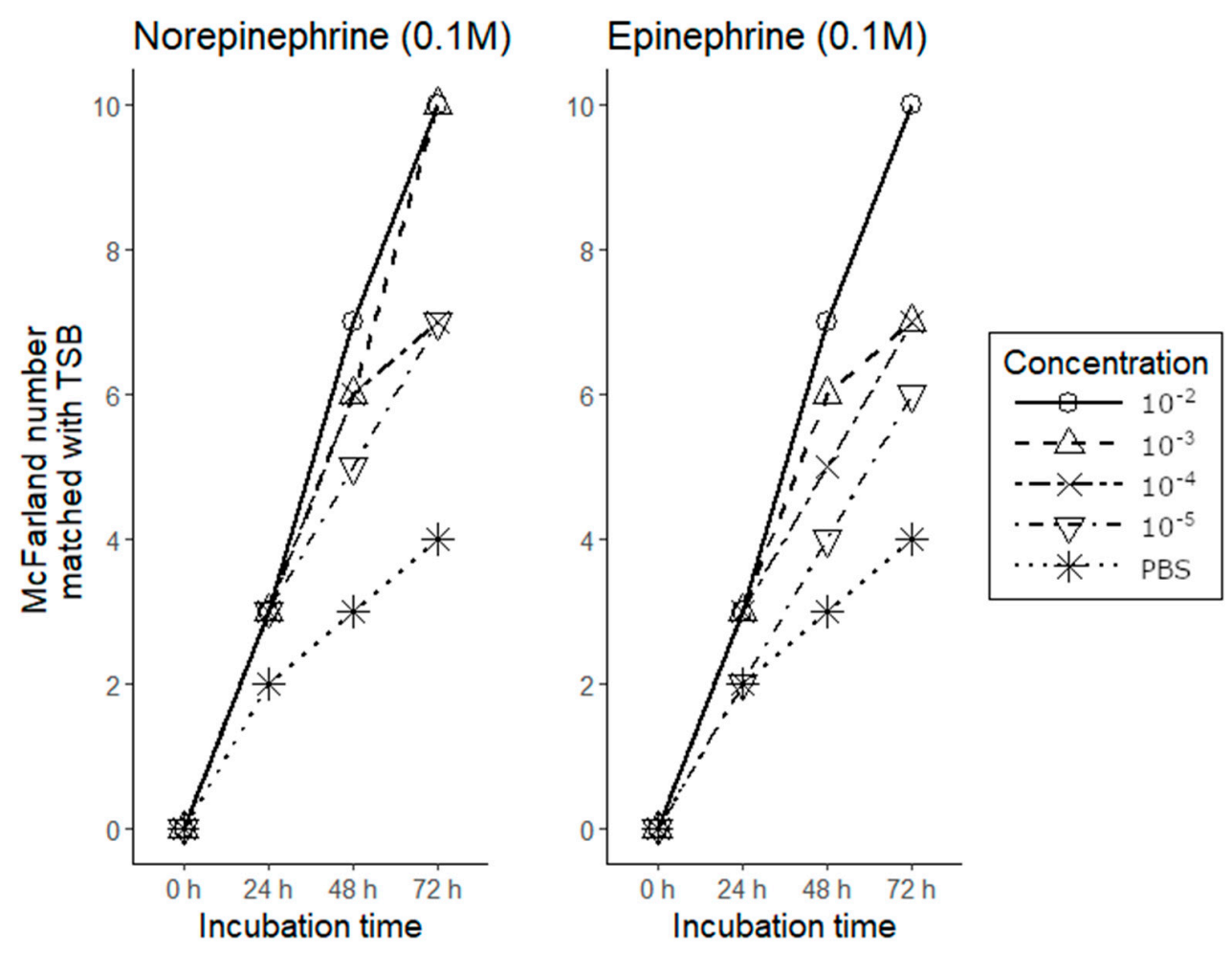

Figure 2. Effect of stress hormones (norepinephrine and epinephrine) on the growth of Aeromonas hydrophila. TSB, tryptic soy broth; PBS, phosphate buffered saline.

\subsection{Effect of Stressors on A. hydrophila Virulence}

In the norepinephrine group, all 10 mice were euthanized within two days of treatment (Table 2). However, in the epinephrine group, only four mice were euthanized. Six mice remained alive at day 4 post-treatment. Concerning physical stresses, all mice in the fasting group died at day 4 post-treatment, but there were no deaths in the low temperature or agitation groups. In addition, $A$. hydrophila alone did not cause any death during the experiment. Notably, A. hydrophila was isolated from all euthanized mice, but not from living mice.

Table 2. Mortality rate of stress-induced mice experimentally infected with Aeromonas hydrophila.

\begin{tabular}{cccccc}
\hline & \multicolumn{4}{c}{ No. of Dead Mice/No. of Mice Alive at the Day after Treatment } \\
\hline Group * & Day 0 & Day $\mathbf{1}$ & Day 2 & Day 3 & Day 4 \\
\hline AH + N & $0 / 10$ & $6 / 4$ & $4 / 0$ & - & - \\
$\mathrm{AH}+\mathrm{P}$ & $0 / 10$ & $2 / 8$ & $0 / 8$ & $2 / 6$ & $0 / 6$ \\
$\mathrm{AH}+\mathrm{F}$ & $0 / 10$ & $0 / 10$ & $0 / 10$ & $4 / 6$ & $6 / 0$ \\
$\mathrm{AH}+\mathrm{L}$ & $0 / 10$ & $0 / 10$ & $0 / 10$ & $0 / 10$ & $0 / 10$ \\
$\mathrm{AH}+\mathrm{S}$ & $0 / 10$ & $0 / 10$ & $0 / 10$ & $0 / 10$ & $0 / 10$ \\
$\mathrm{AH}$ alone & $0 / 10$ & $0 / 10$ & $0 / 10$ & $0 / 10$ & $0 / 10$ \\
PBS & $0 / 10$ & $0 / 10$ & $0 / 10$ & $0 / 10$ & $0 / 10$ \\
\hline
\end{tabular}

${ }^{*}$ Abbreviations: $\mathrm{AH}$, Aeromonas hydrophila; $\mathrm{N}$, norepinephrine; P, epinephrine; F, fasting; L, low temperature; $\mathrm{S}$ agitation; and PBS, phosphate buffered saline.

\subsection{Necropsy and Histopathology}

Compared to the tissues of living mice, lesions compatible with severe tissue damage were observed in several organs. The liver displayed diffuse focal necrosis. The kidney displayed renal tubule necrosis. Severe hemorrhagic signs were observed in lung tissue, and obvious detachment of the villi was observed in the small intestine (Figure 3). 


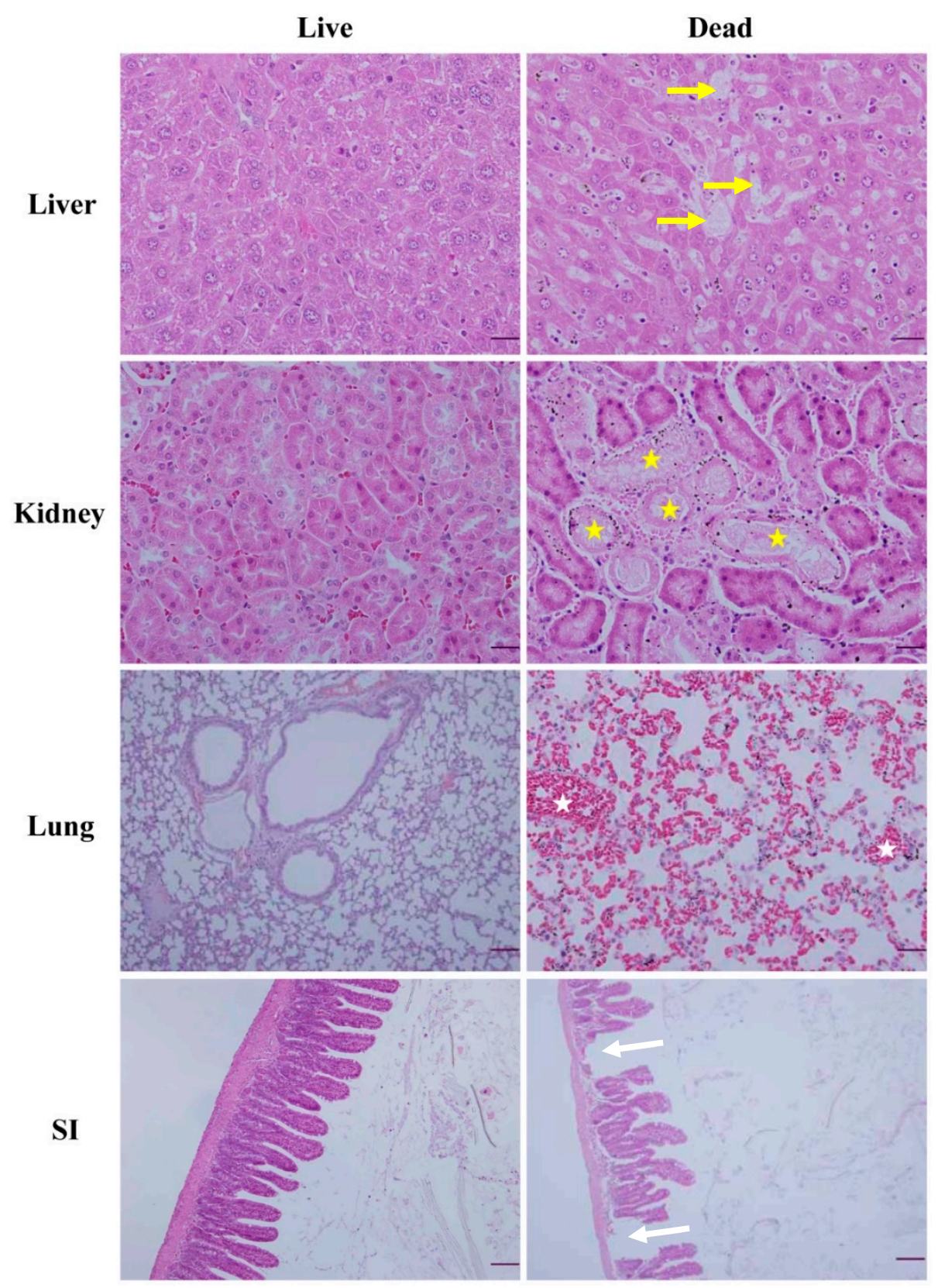

Figure 3. Histopathology of mice infected with Aeromonas hydrophila. Tissue samples including those of the liver, kidney, lung, and small intestine (SI) from dead and living mice were stained with hematoxylin and eosin. The living mice were from mice that were infected with $A$. hydrophila but did not die, and dead mice were from mice that died following infection with $A$. hydrophila. Diffuse vacuole degeneration and necrosis of the infected liver (yellow arrows), tubular necrosis of the infected kidney (yellow stars), severe hemorrhagic signs on lung tissue (white stars), and detached necrosis of SI (white arrows) were observed in dead mice. Bars $(20 \mu \mathrm{m} ; \times 400)$ in liver, kidney, and lung; bars $(200 \mu \mathrm{m} ; \times 40)$ in SI.

Gram staining revealed red and rod-shaped bacteria in liver and heart tissues of the euthanized mice (Figure 4). In situ PCR revealed that the presence of A. hydrophila 16S rRNA, which was detected as light to dark brown staining in the heart, lung, and liver tissues of the dead mice (Figure 4). 


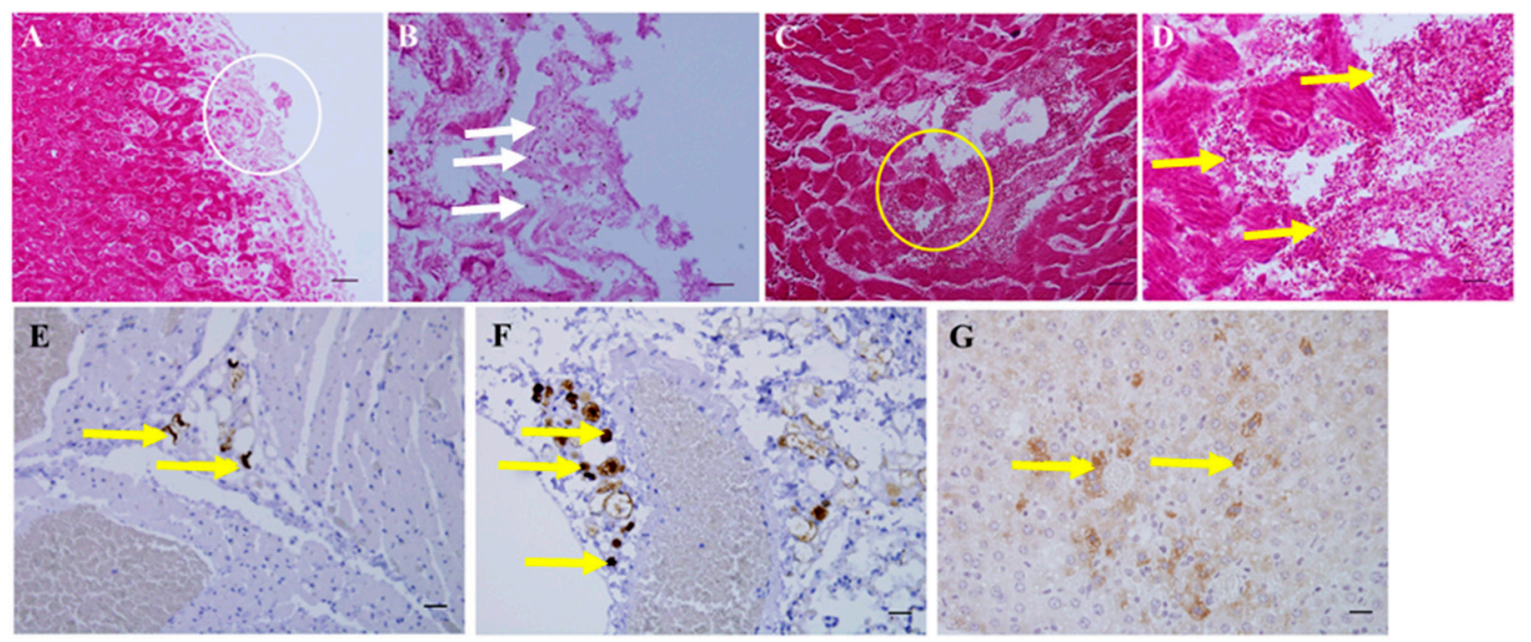

Figure 4. Visualization of Aeromonas hydrophila in mouse tissues using the Lillie's Gram staining (A-D) and in situ PCR (E-G). A, bacteria in the liver (bar $=50 \mu \mathrm{m} ; \times 200$ ); B, magnification of the image in the white circle in panel A and white arrows pointing to bacteria ( $\mathrm{bar}=10 \mu \mathrm{m} ; \times 1000$ ); $\mathrm{C}$, bacteria in the heart (bar $=20 \mu \mathrm{m} ; \times 400$ ); $\mathrm{D}$, magnification of the image in the yellow circle in panel $C$ with bacteria indicated by the yellow arrows (bar $=10 \mu \mathrm{m} ; \times 1000)$; $\mathrm{E}$, heart $(\mathrm{bar}=20 \mu \mathrm{m}$; $\times 400)$; F, lung (bar $=20 \mu \mathrm{m} ; \times 400)$; and $\mathrm{G}$, liver (bar $=20 \mu \mathrm{m} ; \times 400)$. Yellow arrows in $\mathrm{E}, \mathrm{F}$, and G indicate positivity of in situ PCR.

\subsection{Effect of Serial Passaging on Virulence}

In the oral inoculation group, the first passage resulted in the euthanasia of one mouse $72 \mathrm{~h}$ post-inoculation. The second passage resulted in the euthanasia of one mouse each at 48 and $72 \mathrm{~h}$ post-inoculation. However, in the third passage, all 10 mice were euthanized within $12 \mathrm{~h}$ post-inoculation (Table 3). In the intraperitoneal inoculation group, the first, second, and third passages led to the euthanasia of all mice at 48, 24, and within $12 \mathrm{~h}$ post-inoculation, respectively.

Table 3. Mortality of mice experimentally infected with Aeromonas hydrophila according to the administration route after serial passaging.

\begin{tabular}{ccccccc}
\hline \multirow{2}{*}{$\begin{array}{c}\text { Passage } \\
\text { Number }\end{array}$} & $\begin{array}{c}\text { Route of } \\
\text { Inoculation }\end{array}$ & \multicolumn{4}{c}{ No. of Dead Mice/No. of Mice Alive Post Infection } \\
\cline { 3 - 6 } 1st & $\mathbf{0 ~ h}$ & $\mathbf{1 2} \mathbf{h}$ & $\mathbf{2 4} \mathbf{h}$ & $\mathbf{4 8} \mathbf{h}$ & $\mathbf{7 2} \mathbf{h}$ \\
\hline \multirow{2}{*}{ 2nd } & Oral & $0 / 10$ & $0 / 10$ & $0 / 10$ & $0 / 10$ & $1 / 9$ \\
& Intraperitoneal & $0 / 10$ & $0 / 10$ & $8 / 2$ & $2 / 0$ & - \\
& PBS * & $0 / 10$ & $0 / 10$ & $0 / 10$ & $0 / 10$ & $0 / 10$ \\
\hline \multirow{2}{*}{$3 r d$} & Oral & $0 / 10$ & $0 / 10$ & $0 / 10$ & $1 / 9$ & $1 / 8$ \\
& Intraperitoneal & $0 / 10$ & $2 / 8$ & $8 / 0$ & - & - \\
& PBS & $0 / 10$ & $0 / 10$ & $0 / 10$ & $0 / 10$ & $0 / 10$ \\
& Oral & $0 / 10$ & $10 / 0$ & - & - & - \\
& Intraperitoneal & $0 / 10$ & $10 / 0$ & - & - & - \\
& PBS & $0 / 10$ & $0 / 10$ & $0 / 10$ & $0 / 10$ & $0 / 10$ \\
\hline
\end{tabular}

ॠPBS, phosphate buffered saline.

During serial passaging, clinical signs were observed. These included diminished consumption of diet, dull behavior, and depression. These signs were more pronounced with intraperitoneal inoculation compared to oral administration. At necropsy, a mildly congested intestine was observed, which was more severe in the intraperitoneal group.

\section{Discussion}

In the previous study [7], the penguin died while in captivity at a zoo, following clinical signs of depression and anorexia with greenish vomitus. At necropsy, dead penguin appeared to have hemorrhage and catarrhal inflammation of the intestines, severe 
enlargement of the right hepatic lobe, elongation of the gall bladder, and pyloric ulceration of the stomach. Microscopic observation revealed congestion, fat droplets within the cytoplasm of the hepatic cell, infiltration of lymphocytes in the stomach, villus detachment, and destroyed glandular epithelium in the small and large intestines. From the liver and intestine of the dead penguin, A. hydrophila, but no other causative agents, was isolated [7].

According to a previous study [22], Proteobacteria including Aeromonas species are natural gut microbiota in penguins. However, stress might lead to Aeromonas infection in case animals with decreased immune functioning [3-5]. In several studies, it was reported that catecholamines (including epinephrine and norepinephrine) increased bacterial growth, virulence-associated factors, adhesions, and biofilm formation and consequently influenced bacterial infections in many hosts [23]. This also has been examined in several aquatic pathogens, including Aeromonas, Edwardsiella, and Vibrio spp. [12,24,25].

In this study, we investigated the virulence of the A. hydrophila isolate in several aspects, such as virulence genes, virulence change in the serial passage (in vivo), and administration of stress hormones (in vitro) or fasting (in vivo). In a previous study [18], $87 \mathrm{~A}$. hydrophila isolates of enteric origin all tested positive for $a h h 1,55 \%$ tested positive for aer $A$, and all tested positive for $16 \mathrm{~S}$ rRNA by multiplex PCR. In the present study, the $A$. hydrophila strain isolated from the dead penguin and the reference strain tested positive for ahh1, aerA, and 16S rRNA by singleplex and multiplex PCR. When 107 A. hydrophila isolates from ready-to-eat meat and cheese in Italy were examined for cytotoxins, all isolates were cytotoxic to Vero cells [21]. Examination of $48 \mathrm{~A}$. hydrophila isolates from seafood detected $79.2 \%$ hemolysin and $91.7 \%$ cytotoxin [26]. In this study, the cytotoxicity of the $A$. hydrophila isolate was assessed according to the method previously described [21,26], and the cytotoxic potential of the isolate was demonstrated in BHK and Vero cells.

In vitro culture of $A$. hydrophila with the norepinephrine and epinephrine stress hormones induced marked bacterial growth, and administration of norepinephrine induced an increase in the growth and virulence of $A$. hydrophila, according to a previous study [12]. The increased bacterial growth may alter the host microenvironment, causing stress to the animal $[7,8,17]$. Bacteria exposed to norepinephrine have increased their ability to infect the host, and the catecholamine has the similar effects on birds [27]. Since the small intestine is richly innervated by noradrenergic nerve fibers and because the secretion of norepinephrine by sympathetic nerve fibers increases under stressful conditions, this response can affect host susceptibility to disease [12].

An important aspect of this study is the verification of the effect of stress conditions on A. hydrophila infection. A. hydrophila-infected mice treated with stress hormones required early euthanasia, as did mice belonging to the fasting subgroup, unlike mice treated with other physical stresses (low temperature and agitation). Thus, starvation may cause more severe stress to animals compared to other physical stresses, including low temperature and agitation. In this study, A. hydrophila was not isolated from the surviving mice subjected to epinephrine but was isolated from mice that died following epinephrine treatment. In addition, when $A$. hydrophila was serially passaged, virulence was enhanced, especially during the third passage. These data suggest that catecholamines may lead stress to animals, and an opportunistic bacterium, A. hydrophila, can cause disease in animals with stress.

Krzyminska et al. [28] reported the enhanced virulence of $A$. caviae isolated from the diarrheal feces of children by serial passaging in mice, with increases in virulence factors including adhesion, siderophores, and cholera-like toxin. In addition, environmental strains of $A$. caviae could be induced to produce aerolysin with three repeated passages in rabbit ileal loops [2,11]. In another study, environmental strains of aeromonads were similarly induced to produce aerolysin with repeated passaging, becoming potentially enterotoxigenic after 1-3 passages in rabbit ileal loops [29]. Presently, when A. hydrophila isolated from the dead penguin was inoculated by three serial passages in mice via the oral and intraperitoneal routes, the mortality of mice dramatically increased with each passage number, especially in the third passage. 
Animals caught and held in captivity for short or long periods show clinical signs similar to those of other captive zoo animals [30]. Furthermore, clinical signs and abnormal behavior tend to become exacerbated with increasing time in captivity [31]. These findings indicate that the diseases observed in captive and wild-caught animals are linked in some way to the captive environment [30]. It is likely that captivity is stressful to animals and that stress is a predisposing factor to poor health and productivity loss during the state of captivity [32]. In this study, stress may not be a direct cause of the death of penguin, but Aeromonas was on the only bacterium isolated from the dead penguin, indicating there is an association between death of penguin and Aeromonas infection. Moreover, the immune function of the stressed animals was not assessed in this study, therefore, further studies are needed to determine molecular differences between the $A$. hydrophila isolated from the penguin, and the $A$. hydrophila recovered from the mice, particularly after passaging, and to examine the immune function of the animals after inducing stress.

\section{Conclusions}

In conclusion, A. hydrophila, which is an opportunistic zoonotic bacterium, has the ability to infect animals with injuries involving the condition of the aquatic environments. Factors including poor sanitation and water quality, stress, overcrowding, and rough handling can make animals more sensitive to infections and trigger outbreaks of $A$. hydrophila. Here, we examined the virulence of $A$. hydrophila, previously isolated from an African black-footed penguin that died while in captivity at a zoo, and confirmed that serial passaging in mice enhanced the virulence of $A$. hydrophila. Moreover, A. hydrophila infection combined with administration of stress hormones or fasting increased mortality of mice.

Author Contributions: Conceptualization, K.-T.K.; methodology, K.-T.K.; validation, D.K.; formal analysis, K.-T.K., K.-K.L.; investigation, K.-T.K.; resources, K.-T.K.; data curation, S.-H.L., K.-K.L.; writing-original draft preparation, K.-T.K.; writing—review and editing, K.-T.K., S.-H.L., K.-K.L., J.E.H., D.K.; visualization, K.-T.K., J.E.H., D.K.; supervision, D.K. All authors have read and agreed to the published version of the manuscript.

Funding: This research received no external funding.

Institutional Review Board Statement: The study was conducted according to the guidelines of the Declaration of Helsinki, and approved by the Institutional Animal Care and Use Committee (approval no. DOTP-200600501) at the Daejeon O-World Theme Park.

Data Availability Statement: Data presented in this study are available within the article.

Conflicts of Interest: The authors declare no conflict of interest.

\section{References}

1. Colwell, R.R.; MacDonell, M.T.; De Ley, J. Proposal to recognize the family Aeromonadaceae. Int. J. Syst. Evol. Microbiol. 1986, 36, 473-477.

2. Janda, J.M. Recent advances in the study of the taxonomy, pathogenicity, and infectious syndromes associated with the genus Aeromonas. Clin. Microbiol. Rev. 1991, 4, 397-410. [CrossRef]

3. Janda, J.M.; Abbott, S.L. The genus Aeromonas: Taxonomy, pathogenicity, and infection. Clin. Microbiol. Rev. 2010, 23, 35-73. [CrossRef]

4. Fernández-Bravo, A.; Figueras, M.J. An update on the genus Aeromonas: Taxonomy, epidemiology, and pathogenicity. Microorganisms 2020, 8, 129. [CrossRef]

5. Austin, B.; Austin, D.A.; Austin, B.; Austin, D.A. Bacterial Fish Pathogens; Springer: Dordrecht, The Netherlands, 2012.

6. Cusick, P.K.; Bullock, B.C. Ulcerative dermatitis and pneumonia associated with Aeromonas hydrophila infection in the bottle-nosed dolphin. J. Am. Vet. Med. Assoc. 1973, 163, 578-579.

7. Kim, K.T.; Cho, S.W.; Son, H.Y.; Ryu, S.Y. Aeromonas hydrophilia infection in Jackass Penguins (Spheniscus demersus). Korean J. Vet. Res. 2005, 45, 381-385.

8. Kim, K.T.; Kwak, D. A case of Aeromonas hydrophila infection due to captivity-induced stress in a spectacled caiman (Caiman crocodilus). J. Anim. Plant. Sci. 2013, 23, 1761-1763.

9. Cardoso, M.D.; Lemos, L.S.; Roges, E.M.; de Moura, J.F.; Tavares, D.C.; Matias, C.A.R.; Rodrigues, D.P.; Siciliano, S.A. Comprehensive survey of Aeromonas sp. and Vibrio sp. in seabirds from southeastern Brazil: Outcomes for public health. J. Appl. Microbiol. 2018, 124, 1283-1293. [CrossRef] 
10. Kirov, S.M. The public health significance of Aeromonas spp. in foods. Int. J. Food Microbiol. 1993, 20, 179-198. [CrossRef]

11. Chopra, A.K.; Houston, C.W. Enterotoxins in Aeromonas-associated gastroenteritis. Microbes Infect. 1999, 1, 1129-1137. [CrossRef]

12. Kinney, K.S.; Austin, C.E.; Morton, D.S.; Sonnenfeld, G. Catecholamine enhancement of Aeromonas hydrophila growth. Microb. Pathog. 1999, 26, 85-91. [CrossRef]

13. Kuge, T.; Takahashi, K.; Barcs, I.; Hayashi, F. Aeromonus hydrophila, a Causative Agent of Mass Mortality in Cultured Japanese Catfish Larvae (Silurus asotus). Fish Pathol. 1992, 27, 57-62. [CrossRef]

14. Thune, R.L.; Stanley, L.A.; Cooper, R.K. Pathogenesis of gram-negative bacterial infections in warmwater fish. Annu. Rev. Fish Dis. 1993, 3, 37-68. [CrossRef]

15. Angka, S.L.; Lam, T.J.; Sin, Y.M. Some virulence characteristics of Aeromonas hydrophila in walking catfish (Clarias gariepinus). Aquaculture 1995, 130, 103-112. [CrossRef]

16. Ullmann, D.; Krause, G.; Knabner, D.; Weber, H.; Beutin, L. Isolation and characterization of potentially human pathogenic, cytotoxin-producing Aeromonas strains from retailed seafood in Berlin, Germany. J. Vet. Med. B 2005, 52, 82-87. [CrossRef] [PubMed]

17. Granum, P.E.; O'Sullivan, K.; Tomas, J.M.; Ormen, O. Possible virulence factors of Aeromonas spp. from food and water. FEMS Immunol. Med. Microbiol. 1998, 21, 131-137. [CrossRef] [PubMed]

18. Wang, G.; Clark, C.G.; Liu, C.; Pucknell, C.; Munro, C.K.; Kruk, T.M.; Caldeira, R.; Woodward, D.L.; Rodgers, F.G. Detection and characterization of the hemolysin genes in Aeromonas hydrophila and Aeromonas sobria by multiplex PCR. J. Clin. Microbiol. 2003, 41, 1048-1054. [CrossRef]

19. Arora, S.; Agarwal, R.K.; Bist, B. Comparison of ELISA and PCR vis-a-vis cultural methods for detecting Aeromonas spp. in foods of animal origin. Int. J. Food Microbiol. 2006, 106, 177-183. [CrossRef]

20. Köbölkuti, L.; Czirjak, G.A.; Spinu, M. Effects of malnutrition and improper captive maintenance on European pond turtle (Emys orbicularis): A case report. J. Anim. Plant Sci. 2016, 26, 874-879.

21. Martins, L.M.; Marquez, R.F.; Yano, T. Incidence of toxic Aeromonas isolated from food and human infection. FEMS Immunol. Med. Microbiol. 2002, 32, 237-242. [CrossRef]

22. Dewar, M.L.; Arnould, J.P.; Dann, P.; Trathan, P.; Groscolas, R.; Smith, S. Interspecific variations in the gastrointestinal microbiota in penguins. Microbiologyopen 2013, 2, 195-204. [CrossRef] [PubMed]

23. Sarkodie, E.K.; Zhou, S.; Baidoo, S.A.; Chu, W. Influences of stress hormones on microbial infections. Microb. Pathog. 2019, 131, 270-276. [CrossRef] [PubMed]

24. Nakano, M.; Takahashi, A.; Sakai, Y.; Nakaya, Y. Modulation of pathogenicity with norepinephrine related to the type III secretion system of Vibrio parahaemolyticus. J. Infect. Dis. 2007, 195, 1353-1360. [CrossRef]

25. Wang, X.; Wang, Q.; Yang, M.; Xiao, J.; Liu, Q.; Wu, H.; Zhang, Y. QseBC controls flagellar motility, fimbrial hemagglutination and intracellular virulence in fish pathogen Edwardsiella tarda. Fish Shellfish Immunol. 2011, 30, 944-953. [CrossRef]

26. Tsai, G.J.; Chen, T.H. Incidence and toxigenicity of Aeromonas hydrophila in seafood. Int. J. Food Microbiol. 1996, 31, $121-131$. [CrossRef]

27. Borsoi, A.; Quinteiro-Filho, W.M.; Calefi, A.S.; Piantino Ferreira, A.J.; Astolfi-Ferreira, C.S.; Florio, J.C.; Palermo-Neto, J. Effects of cold stress and Salmonella Heidelberg infection on bacterial load and immunity of chickens. Avian Pathol. 2015, 44, 490-497. [CrossRef]

28. Krzymińska, S.; Mokracka, J.; Laganowska, M.; Włodarczak, K.; Guszczyńska, E.; Liszkowska, J.; Popkowska, E.; Lima, I.; Lemańska, I.; Wendt, M. Enhancement of the virulence of Aeromonas caviae diarrhoeal strains by serial passages in mice. J. Med. Microbiol. 2001, 50, 303-312. [CrossRef]

29. Singh, D.V.; Sanyal, S.C. Enterotoxicity of clinical and environmental isolates of Aeromonas spp. J. Med. Microbiol. 1992, 36, 269-272. [CrossRef]

30. Carlstead, K.; Shepherdson, D. Alleviating stress in zoo animals with environmental enrichment. In The Biology of Animal Stress: Basic Principles and Implications for Animal Welfare; Moberg, G.P., Mench, J.A., Eds.; CABI Publishing: London, UK, 2000; pp. 337-354.

31. Munson, L.; Nesbit, J.W.; Meltzer, D.G.A.; Colly, L.P.; Bolton, L.; Kriek, N.P.J. Diseases of captive cheetahs (Acinonyx jubatus jubatus) in South Africa: A 20-year retrospective survey. J. Wildl. Dis. 1999, 30, 342-347.

32. St Aubin, D.J.; Dierauf, L.A. Stress and marine mammals. In CRC Handbook of Marine Mammal Medicine: Health, Disease, and Rehabilitation, 2nd ed.; Dierauf, L.A., Gulland, F.M.D., Eds.; CRC Press: Boca Raton, FL, USA, 2001; pp. $253-269$. 